Omni-Akuatika, 15 (2): $106-113,2019$
ISSN: 1858-3873 print / 2476-9347 online
Research Article
journal homepage: http://ojs.omniakuatika.net

\title{
Study of Symbiont Bacteria of Acropora digitifera Coral From Ciletuh Bay, Sukabumi by Using Culture and Molecular Approach
}

\author{
Nurfitri ${ }^{1,4}$, Fiddy Semba Prasetiya ${ }^{2,4,5}$, Indah Riyantini ${ }^{2}$, Yuniar Mulyani ${ }^{3,4}$, Sulastri Arsad $^{6,7}$, \\ Mochamad Untung Kurnia Agung ${ }^{2,4^{*}}$ \\ ${ }^{1}$ Study Programme of Marine Science, Faculty of Fisheries and Marine Sciences, Universitas Padjadjaran, الJ. \\ Raya Bandung-Sumedang KM 21 Jatinangor, Sumedang, West Java 45363, Indonesia \\ ${ }^{2}$ Department of Marine Science, Faculty of Fisheries and Marine Sciences, Universitas Padjadjaran, Jl. Raya \\ Bandung-Sumedang KM 21 Jatinangor, Sumedang, West Java 45363, Indonesia \\ ${ }^{3}$ Department of Fisheries, Faculty of Fisheries and Marine Sciences, Universitas Padjadjaran Jl. Raya Bandung- \\ Sumedang KM 21 Jatinangor, Sumedang, West Java 45363, Indonesia \\ ${ }^{4}$ Laboratory of Microbiology and Molecular Biotechnology (MICROMOL), Faculty of Fisheries and Marine \\ Sciences, Universitas Padjadjaran, Jl. Raya Bandung-Sumedang KM 21 Jatinangor, Sumedang, West Java \\ 45363, Indonesia \\ ${ }^{5}$ Research Center of Molecular Biotechnology and Bioinformatics, Universitas Padjadjaran, Jl. Singaperbangsa \\ No. 2, Bandung, West Java 40132, Indonesia \\ ${ }^{6}$ Study Programme of Aquatic Resources Management, Faculty of Fisheries and Marine Sciences, Universitas \\ Brawijaya, Malang 65145, Indonesia \\ ${ }^{7}$ Research Center of Microbiology Resources and Technology (MicroBase), Postgraduate Programme Universitas \\ Brawijaya, Jl. Veteran Malang 65145, JawaTimur, Indonesia \\ ${ }^{*}$ Corresponding author: mochamad.untung@unpad.ac.id
}

Received 24 Oktober 2019; Accepted 20 November 2019; Available online 31 November 2019

\begin{abstract}
Bacteria are one of the prokaryotic microorganisms that are symbiotic with coral reefs. These microorganisms help corals in secreting mucus layers which are used as a place to live for bacteria and control the presence of pathogenic bacteria in corals. The purpose of this study was to determine the diversity of bacterial communities associated with Acropora digitifera corals in Ciletuh bay, West Java, by culture approach. Sampling was carried out at a depth of 4 meters. Morphology-based identification and molecular approach based on sequence of the small ribosomal unit (16S) rRNA gene were used to determine the bacterial species in the samples. A total of six pure isolates were identified based on morphological observation and the molecular DNA characteristics from three of them were identified with 16S rRNA gene sequences. The identification using 16S rRNA gene showed that the isolate ACD.P4.PH7.P had a close relationship with the BF strain and zb strain of Bacillus flexus (acc number MH569560.1) with a similarity of $85.44 \%$. While ACD.P4.PH9.P isolate has a close relationship with Bacillus sp. c234 (acc number FJ950647.1) with a similarity of $98.50 \%$. Additionally, ACD.P4.PH9.K isolates closely related to Bacillus sp. of strain 6RM1 (acc number MK134607.1) with a similarity of $94.78 \%$. This study also revealed that both microscopic identifications by morphological traits and molecular approach using 16S rRNA gene can be used in bacterial diversity assessment.
\end{abstract}

Keywords: Acropora digitifera, bacteria, 16S rRNA gene, culture, gene sequence

\begin{abstract}
ABSTRAK
Bakteri adalah salah satu mikroorganisme prokariotik yang bersimbiosis dengan terumbu karang. Mikroorganisme ini membantu karang dalam mengeluarkan lapisan lendir yang digunakan sebagai tempat hidup bakteri dan mengendalikan keberadaan bakteri patogen di dalam karang. Tujuan dari penelitian ini adalah untuk menentukan keanekaragaman komunitas bakteri yang terkait dengan karang Acropora digitifera di teluk Ciletuh, Jawa Barat, dengan pendekatan kultur. Pengambilan sampel dilakukan pada kedalaman 4 meter. Identifikasi berbasis morfologi dan pendekatan molekuler berdasarkan sekuen gen rRNA unit ribosom kecil (16S) digunakan untuk menentukan spesies bakteri
\end{abstract}


dalam sampel. Sebanyak enam isolat murni diidentifikasi berdasarkan pengamatan morfologis dan karakteristik DNA molekuler dari tiga di antaranya diidentifikasi dengan sekuens gen 16S rRNA. Identifikasi menggunakan gen 16S rRNA menunjukkan bahwa isolat ACD.P4.PH7.P memiliki hubungan yang erat dengan strain BF dan strain zb Bacillus flexus (nomor acc MH569560.1) dengan kesamaan $85,44 \%$. Sedangkan isolat ACD.P4.PH9.P memiliki hubungan erat dengan Bacillus $\mathrm{sp}$. c234 (nomor acc FJ950647.1) dengan kesamaan 98,50\%. Selain itu, isolat ACD.P4.PH9.K terkait erat dengan Bacillus sp. dari strain 6RM1 (nomor acc MK134607.1) dengan kesamaan 94,78\%. Studi ini juga mengungkapkan bahwa kedua identifikasi mikroskopis dengan ciri-ciri morfologis dan pendekatan molekuler menggunakan gen 16S rRNA dapat digunakan dalam penilaian keanekaragaman bakteri.

Kata kunci: Acropora digitifera, bakteri, gen 16S rRNA, kultur, sekuen gen

\section{Introduction}

Ciletuh Bay is located in the district of Sukabumi, West Java, Indonesia. This bay has a diverse coral reef ecosystem, both hard coral (Scleractinian) and soft corals that have holobiont with microorganisms around them, such as bacteria and zooxanthellae and other microorganisms. One of the associations between coral reefs and microorganisms is their mutual symbiosis in producing oxygen. There are various types of hard coral in these waters and one of them is Acropora digitifera. This species is a type of hard coral commonly found in the Indonesian Ocean which belongs to the family Acroporidae. Corals that belong to this family are commonly found in depths of 315 meters.

According to Utama (2017), there arefiftyeight coral species from the Acroporidae family in Indonesia, including Acropora abrolhonsensis, Acropora aspera, Acropora austrea, Acropora bifurcata, Acropora cerealis, Acropora clathrata, Acropora cytherea, Acropora digitifera, Acropora divaricata, Acropora formosa, Acropora gemmifera, Acropora humilis, Acropora hyacinthus, Acropora jacqueline, Acropora kimbeensis, Acropora listeri, Acropora loripes, Acropora microlados, Acropora millepora, Acropora monticulosa, Acropora nasuta, Acropora pulchra, Isopora palifera, Acropora retusa, Acropora robusta, Acropora samoensis, Acropora sarmentosa, Acropora secale, Acropora selago, Acropora seriata, Acropora solitaryensis, Acropora sp., Acropora spicifera, Acropora stoddarti, Acropora tenuis, Acropora valida, Acropora yongei, Astreopora ocellata, Astreopora sp., Isopora bruggemi, Isopora cuneata, Montipora caliculata, Montipora efflorescens, Montipora flaveolata, Montipora florida, Montipora foliosa, Montipora grissea, Montepora hispida, Montipora incrassata, Montipora informis, Montipora monasteriata, Montipora peltiformis, Montipora sp., Montipora tuberculosa, Montipora undata, and Montipora venosa.

Coral reefs are symbiotic or associated with microorganisms to sustain life, one of which is associated with bacteria. In addition to sustaining coral life, bacteria can also affect coral health, nutrient intake, and coral disease (Zhang et al. 2015). One of the methods carried out by coral animals to initiate associations with bacteria is by secreting mucous layers containing glycoprotein.

The mucus layer has a dual role in the association process. In addition to its role of providing living space for the associated bacteria, the layer also has a role in controlling the presence of pathogenic bacteria, together with the secretion of several secondary metabolites that are antibiotics (Ritchie and Smith 1997). The existence of bacterial communities which are in symbiosis with coral reefs can be influenced by seasonal changes, geographical differences, and pollution (Zhang et al. 2015).

These factors can affect the diversity of bacterial communities in coral reefs. The presence of bacteria in the coral reef can be assessed by using culture method. This conventional method can be used for coral species identification by molecular approach. Additionally, previous study from Rinanda (2011) also demonstrated that the bacterial diversity can be conducted by isolating DNA from cultured bacteria, either from solid or liquid culture.

The purpose of this study was to determine the diversity of bacterial communities that are associated with Acropora digitifera corals in the water bodies of Ciletuh bay, Sukabumi, West Java, through a culture approach.

\section{Materials and Methods}

Acropora digitifera coral samples were taken from Ciletuh bay on coordinate 
07011'16.11" LS and 106²5'20.40" BT. Samples were then analyzed in the Laboratory of Microbiology and Molecular Biotechnology, Faculty of Fisheries and Marine Sciences, Universitas Padjadjaran.

\subsection{Sampling of Acropora digitifera corals}

Acropora digitifera coral samples were taken from the depth of 4 meters from corals with sizes of approximately $10 \mathrm{~cm}$ and placed into a plastic bottle containing $70 \%$ ethanol. Then they were stored in a coolbox for temporary storage and brought to the laboratory.

\subsection{Bacterial screening and Morphological observations}

Bacterial screening was carried out in several stages, i.e. inoculation and cultivation of bacterial colonies to determine their morphological traits and gram staining of bacterial cells to determine their shape and color. Briefly, the coral sample was crushed using a mortar. Then, a total of $1 \mathrm{~g}$ of sample was taken for serial dilution (7 times) in a test tube containing $9 \mathrm{ml}$ of sterile seawater and then vortexed.

Bacterial inoculation was carried out by the spread plate method following the protocol from Cappuccino and Welsh (2018). Briefly, a total of $100 \mu \mathrm{l}$ was taken from the sample at dilutions 4 and 5 , then spread on the Zobell Marine Agar (Marine Agar 2216) medium produced by HiMedia Laboratories Pvt. Ltd. Mumbai-400086 India with its brand, HIMEDIA and has catalog number M384-500G in a petri dish and flattened using spreader.

The edge of the petri dish containing bacterial suspension then rotated on a bunsen which was then sealed using a plastic wrap, and incubated for $24 \mathrm{~h}$. After 24 hours, the colony morphology of bacteria was observed and identified according to their shape, color and edges of each isolates. Afterwards, the bacterial colony was then purified using the streak plate technique. In brief, one ose of bacterial isolates were taken from the inoculation results, then etched into a petri dish containing Zobell Marine media.

Moreover, to divide the petri dish into four quadrants, the edge of the petri dish was rotated on a bunsen which was then sealed using plastic wrap and incubated for $24 \mathrm{~h}$. After inoculation and bacterial cultivation, gram staining was performed according to the protocol from Cappuccino and Welsh (2018) to determine the shape and color of the associated bacterial cells. Briefly, one colony from the results of cultivation was taken with an ose needle, then placed on a glass object assisted by physiological $\mathrm{NaCl}$ and allowed to pass on fire.

Afterwards, one drop of gentian violet was added into the object glass and left for $20 \mathrm{~s}$, and washed with distilled water. Then, one drop of iodine solution was dropped into the object glass and left for $1 \mathrm{~min}$, then washed with alcohol and distilled water. Furthermore, one drop of safranin or fuchsin water was then added and left for $20 \mathrm{~s}$, and washed with distilled water. The object glass was then dried and observed on a microscope with a magnification of $40 \mathrm{X}$. Each bacterial isolates was labeled to ease identification.

\subsection{Molecular Identification of Bacteria}

After pure bacterial isolates were obtained from the culture, the liquid culture was then prepared using Nutrient Broth (NB) media to be produced by OXOID Limited Wade Road, Basingtoke, Hampshirw, RG24 SPW, UK with its brand, OXOID and has catalog number CM0001 which would be used for DNA extraction of bacterial genomes. The bacterial genome DNA was extracted using the Wizard Genomic DNA Purification Kit (Promega) protocol for samples of gram positive and gram negative bacteria.

When the bacterial DNA was obtained, PCR was performed to amplify DNA. The primer used for PCR is the 16S rRNA gene in accordance to Lane (1991), which is a $27 \mathrm{~F}$ abd 1492R universal primer. The PCR cycling parameters consisted of an initial denaturation step at $95^{\circ} \mathrm{C}$ for $3 \mathrm{~min}$, denaturation at $95^{\circ} \mathrm{C}$ for $45 \mathrm{~s}$, annealing step at $52^{\circ} \mathrm{C}$ for $1 \mathrm{~min}$, elongation step at $72^{\circ} \mathrm{C}$ for $2 \mathrm{~min}$, final elongation at $72^{\circ} \mathrm{C}$ for $5 \mathrm{~min}$ and $\mathrm{HOLD}$ at $4^{\circ} \mathrm{C}$ for $7 \mathrm{~min}$.

The mixture of PCR products consist of PromTaq ${ }^{\circledR}$ Green Master Mix Promega (12.5 $\mu \mathrm{L}), 27 \mathrm{~F}$ primers $(1.25 \mu \mathrm{L}), 1492 \mathrm{R}$ primers $(1.25 \mu \mathrm{L})$, Nuclease free water $(8 \mu \mathrm{L})$, and DNA template $(2 \mu \mathrm{L})$ thus the total of PCR product is $25 \mu \mathrm{L}$. In this study, $1 \mathrm{~Kb}$ of DNA Ladder (KAPA) as a DNA size marker and DNA Loading dye as a DNA ballast were used. Red Nucleic Acid Gel Stain was used as much as $10 \mu \mathrm{L}$ in $100 \mathrm{~mL}$ of TAE $1 \mathrm{X}$ for $1 \%$ agarose gel.

Then, electrophoresis was performed to determine the presence of genomic DNA bands for 45 minutes with an 80 volt current. Afterwards, Sanger sequencing was performed 
by $1^{\text {st }}$ Base in Singapore. The sequencing stage was carried out at Singapore's 1st Base with results in the form of a FASTA file. The file was then processed by BioEdit and MEGA7 software for phylogenetic tree analysis.

\subsection{Data Analyses}

All data regarding bacterial colony morphology, shape and characteristics of bacterial cells were analyzed descriptively, whereas the FASTA files obtained from sequencing were processed using the BioEditTM software. These FASTA files were then processed further in BLAST in the National Center for Biotechnology Information website (www.ncbi.nlm.nih.gov).

Homogeneous BLAST results were deposited to the GenBank in order to obtain an access number that can be used to construct phylogenetic trees using MEGA 7 software. This was performed to obtain information related to the bacteria's relationship with their isolates. All data that were obtained, were analyzed comparatively and descriptively.

\section{Results and Discussions}

3.1. Bacterial screening and Morphological observations

A total of 6 bacterial isolates were obtained from the Acropora digitifera coral symbiont. These bacterial isolates were obtained from treatments of $\mathrm{pH} 7$ and $\mathrm{pH} 9$ with a dilution rate of 4 and 5 , respectively. According to our morphological observations, from these 6 isolates, the bacterial isolate ACD.P4.PH7.P had similarity to ACD.P5.PH7.P isolate, while the isolate ACD.P4.PH9.P had similarity with ACD.P5.PH9.P isolate. Moreover, the isolate ACD.P4.PH9.K was similar to ACD.P5.PH9.K (Table 1).

\subsection{DNA Isolation of Bacterial Genome}

Based on the inoculation results above (Table 1), there were 6 isolates with similarities and differences. From these isolates, bacterial DNA isolation was then carried out using the Wizard Genomic DNA Purification Kit (Promega) where the results are attached in the Figure 1.

The visualization results of bacterial genome revealed that the DNA band of the bacterial genome is located above 10,000 base pairs (bp). This is due to the genome size that is greater than 10,000 bp. As demonstratedby Demerdash (2012) that bacterial DNA molecules have large sizes, which range from21,000 to $23,000 \mathrm{bp}$

The differences in DNA bands among the samples was probably caused by certain factors. Thick DNA bands show high concentrations and total DNA which were extracted intactly and have high purity too (Mulyani et al, 2011), whereas thin DNA bands could be caused by excessive physical movement during pipetting, or when flipping the solution and other factors.

Based on Figure 2, it can be deduced that the 16S rRNA gene amplification process of Acropora digitifera associated-bacteria using PCR was successfully performed. This also supported by the visualization results where PCR was marked by thick DNA band, and it also shows that the DNA sample band size is in accordance with the product target size $( \pm$ $1465 \mathrm{bp})$. This can be observed from the produced DNA band's position that was situated between 1200 and $1600 \mathrm{bp}$. Thus, the used primers and PCR conditions amplify well in accordance to the primary target of $16 \mathrm{~S}$ rRNA (Lauro et al. 2009).

Smears contained in the electropherogram results can be caused by the presence of contaminants in the form of either protein or the carryover of the remnants of the solution that is present when the DNA isolation process takes place (lqbal, 2016). The same thing stated by Mulyani (2011), the smear seen during the visualization process can take the form of a solution that is still carried away during DNA isolation or it can also be degraded DNA in the DNA isolation process.

Table 1. Morphological characteristics of bacterial isolates from Acropora digitifera

\begin{tabular}{cccccccc}
\hline & \multicolumn{4}{c}{ Bacterial Colonies Morphology } & & \multicolumn{2}{c}{$\begin{array}{c}\text { Bacterial Cells } \\
\text { Morphology }\end{array}$} \\
\cline { 2 - 8 } & Isolat Name & Elevation & Margin & Whole Colony & $\begin{array}{c}\text { Color } \\
\text { Colony }\end{array}$ & Shape & Gram \\
\hline 1. & ACD.P4.PH7.P & Raised & Smooth, entire & Round & White & Streptobacillus & Negative \\
2. & ACD.P5.PH7.P & Raised & Smooth, entire & Round & White & Bacillus & Positive \\
3. & ACD.P4.PH9.P & Convex & Smooth, entire & Round & White & Bacillus & Positive \\
4. & ACD.P4.PH9.K & Convex & Smooth, entire & Round & Yellow & Bacillus & Positive \\
5. & ACD.P5.PH9.P & Convex & Smooth, entire & Round & White & Streptococcus & Negative \\
6. & ACD.P5.PH9.K & Convex & Smooth, entire & Round & Yellow & Streptobacillus & Negative \\
\hline
\end{tabular}




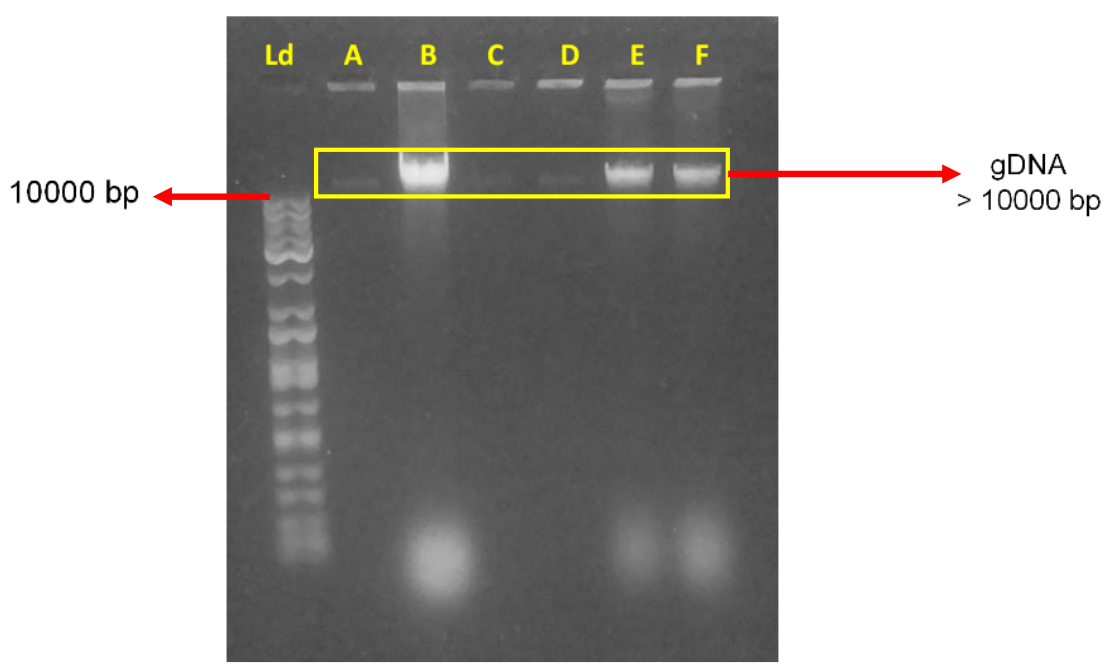

Figure 1. Genome DNA Visualization of the Acropora Digitifera associated-bacteria in $0.8 \%$ Agarose Gel, Ld: 1Kb DNA Ladder (KAPATM), A: Isolate ACD.P4.PH7.P, B: Isolate ACD.P5.PH7.P, C: Isolate ACD.P4.PH9.P, D: Isolate ACD.P4.PH9.K, E: Isolate ACD.P5.PH9.P, F; Isolate ACD.P5.PH9.K

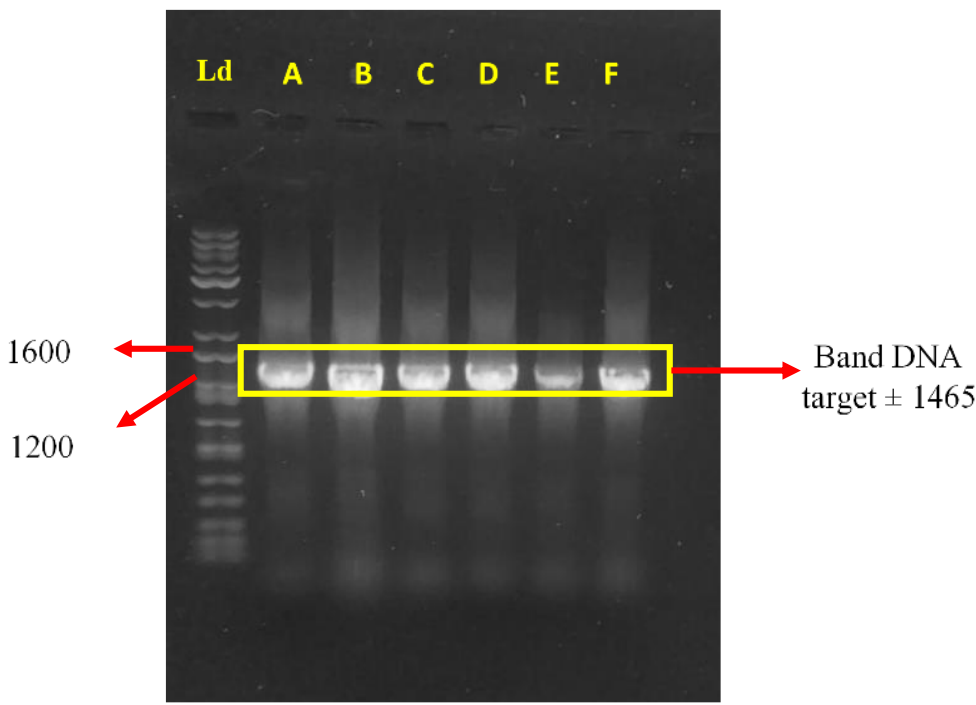

Figure 2. Gene Amplification Results of $16 \mathrm{~S}$ rRNA with $27 \mathrm{~F}$ and $1492 \mathrm{R}$ primers in $0.8 \%$ agarose gel, Ld: 1Kb DNA Ladder (KAPATM), A: Isolate ACD.P4.PH7.P, B: Isolate ACD.P5.PH7.P, C: Isolate ACD.P4.PH9.P, D: Isolate ACD.P4.PH9.K, E: Isolate ACD.P5.PH9.P, F; Isolate ACD.P5.PH9.K

With the availability of DNA band that was in accordance with the target length of its base, the amplification results were ready for sequencing.

3.3. Nucleotide Sequences Analysis from Sanger Sequencing and Phylogenetic Trees Reconstruction

The amplified sample was then sent for sanger sequencing. Furthermore, the obtained results were in the form of nucleotide bases from three sequenced bacterial samples in which the data consist of forward sequences and reverse sequences in .ab1 and seq formats. The nucleotide sequence was then processed using BioEdit ${ }^{\mathrm{TM}}$ software in which the results were consensus of forward and reverse sequences.

The consensus results were further processed to match the available data at GenBank in NCBI (National Center of Biotechnology Information) by using the Nucleotide BLAST program in the Nucleotide collection (nr / nt) database with its bacterial organisms (taxid: 2) online. The identification results of the three sequenced bacterial samples are presented in Table 2.

The percentage of query cover from the 
Table 2. Identification results of Bacterial 16S rRNA gene with BLAST Program

\begin{tabular}{cclcccc} 
No. & Isolate Code & \multicolumn{1}{c}{ Species } & $\begin{array}{c}\text { Query } \\
\text { Cover }\end{array}$ & $\begin{array}{c}\text { E } \\
\text { value }\end{array}$ & $\begin{array}{c}\text { Identity } \\
(\%)\end{array}$ & $\begin{array}{c}\text { Accesion } \\
\text { Number }\end{array}$ \\
\hline 1. & ACD.P4.PH7.P & Bacillus flexus strain Bf strain zb & $99 \%$ & 0,0 & 85,44 & MH569560.1 \\
2. & ACD.P4.PH9.P & Bacillus sp. c234 & $100 \%$ & 0,0 & 98,50 & FJ950647.1 \\
3. & ACD.P4.PH9.K & Bacillus sp. strain 6RM1 & $100 \%$ & 0,0 & 94,78 & MK134607.1 \\
\hline
\end{tabular}

three samples BLAST ranged from 99-100\% (BLAST). This results are in coherence with the Claverie and Notredame (2003) where the query coverage value of above $80 \%$ is moderately high. Therefore, the high percentage of query cover from our samples indicating a high similarity of the base length of the data sequence from samples with those in the Genbank (Miller et al. 1990).

The identity values of the three samples ranged from 85 - $98 \%$ where the ACD.P4.PH7.P sample had the lowest percentage (85.44\%). In contrast, the ACD.P4.PH9.P sample had the highest percentage $(98.50 \%)$. Identity values above $97 \%$ indicate that the species found in the sample had higher similarity to those in the Genbank and is not a new species (Pangastuti 2006) as shown in the ACD.P4.PH9.P sample which has an identity value of $98.50 \%$ with the species Bacillus sp.

While for ACD.P4.PH9.K sample, the identity value is lower than $97 \%$ indicating that the species obtained in the sample is considered as a new species within the same genus, i.e. Bacillus. Our result is supported by Drancourt et al. (2000) which stated that $16 \mathrm{~S}$ rRNA gene sequence data that has an identity value of $\leq 97 \%$ indicates that the species are in the same genus where as the identity value between $89-93 \%$ shows that the species are in the same family but different genus. On the other hand, the sample ACD.P4.PH7.P has an identity value of $85.44 \%$, suggesting that the species are situated in the different family.
The results of phylogenetic tree reconstruction in the sequence ACD.P4.PH7.P showed a close relationship with the species Bacillus flexus of strain $\mathrm{Bf}$ and strain $\mathrm{zb}$ (Acc. No. MH569560.1, Figure 3). Moreover, the obtained phylogenetic tree construction revealed that the sequence ACD.P4.PH7.P has a bootstrap value of $30 \%$ and an identity of $85.44 \%$. This means that from the phylogeny tree reconstruction of a thousand times, the sequence ACD.P4.PH7.P has a $30 \%$ relationship with Bacillus flexus of strain $\mathrm{Bf}$ and strain zb (Acc. No. MH569560.1).

Bacillus flexus bacteria, which is classified from the genus of Bacillus, is a gram-positive, rod-shaped, motile bacteria. The genus Bacillus has various roles especially in the fields of bioremediation. This genus has the abilities to degrade organic compounds such as protein, starch, cellulose, and hydrocarbons. Additionally, this genus also capable of producing antibiotics, plays animportant role in nitrification and dentrification, nitrogen fixing, chemolitotrophic and thermophilic (Claus and Berkeley, 1986). As demonstrated by Jebeli et al. 2017, that Bacillus flexus has the ability to remediate arsenic from water [As (V) (28\%) and As (III) $(45 \%)]$, especially in batch conditions.

Based on Figure 4, the sequence ACD.P4.PH9.P has a close relationship with the species Bacillus sp. c234 (Acc. No. FJ950647.1). The bootstrap value between the two sequences is higher than the ACD.P4.PH7.P sequence, which is $55 \%$ with

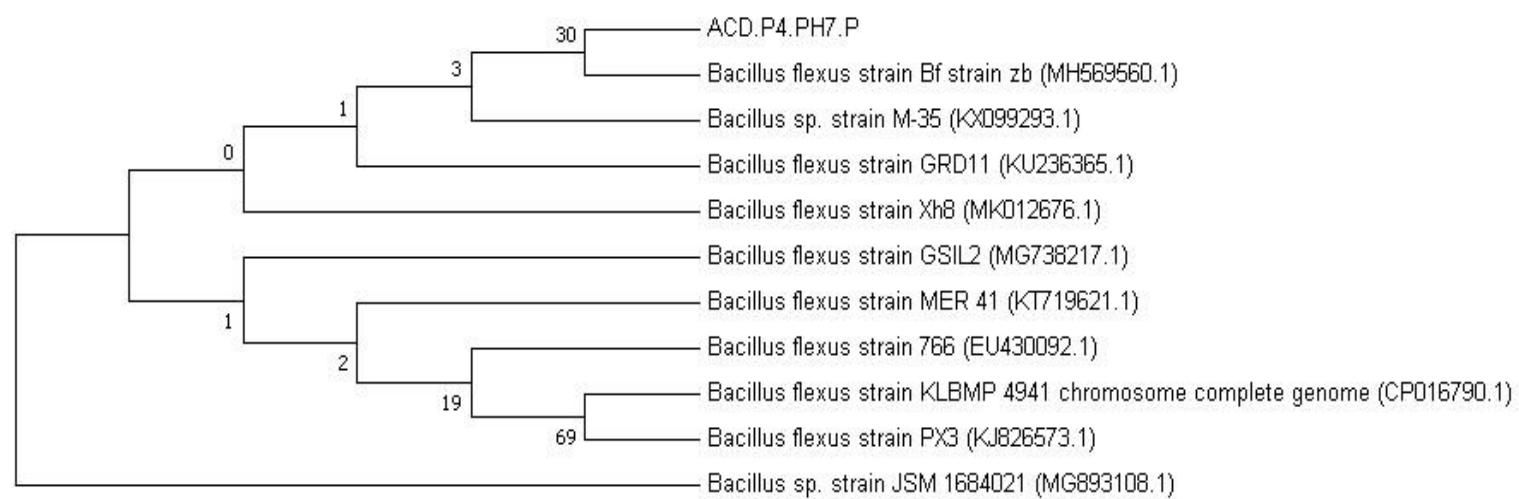

Figure 3. Phylogeny Tree of ACD.P4.PH7.P Bacteria Isolate Based on 16S rRNA Sequence Neighbor - Joining Method, Bootstrap 1000x 


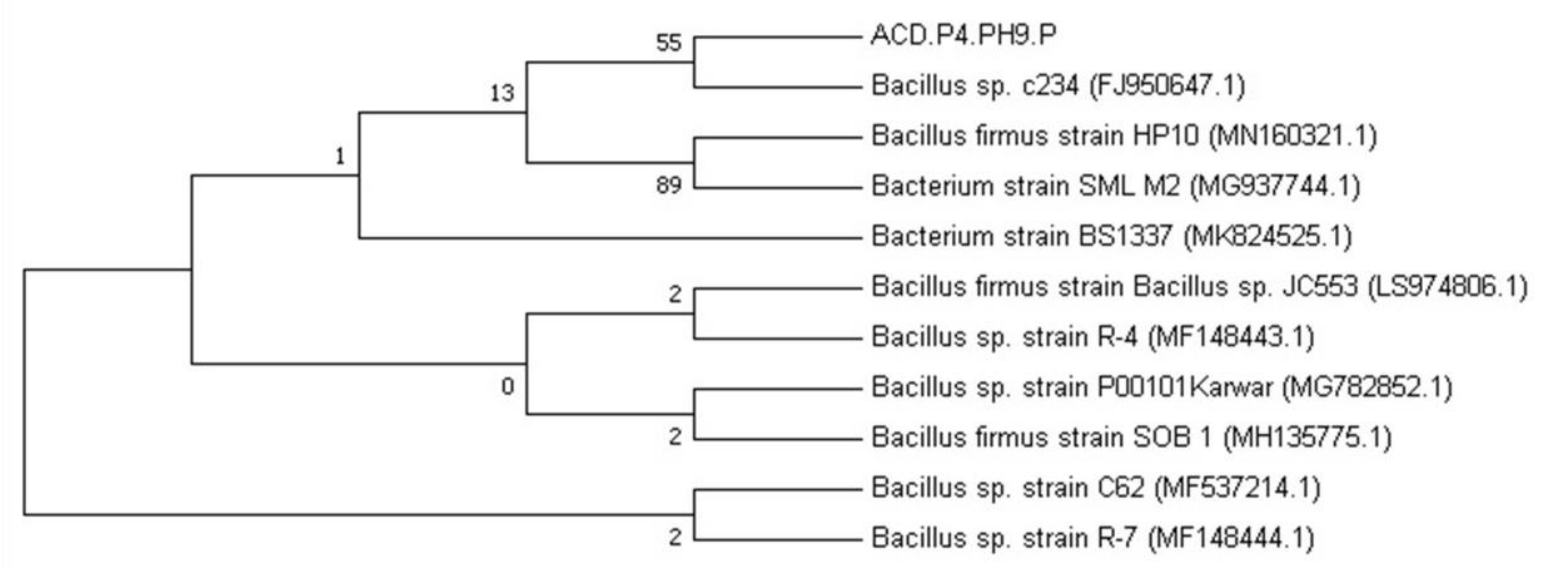

Figure 4. Phylogeny Tree of ACD.P4.PH9.P Bacteria Isolate Based on 16S rRNA Sequence Neighbor - Joining Method, Bootstrap 1000x

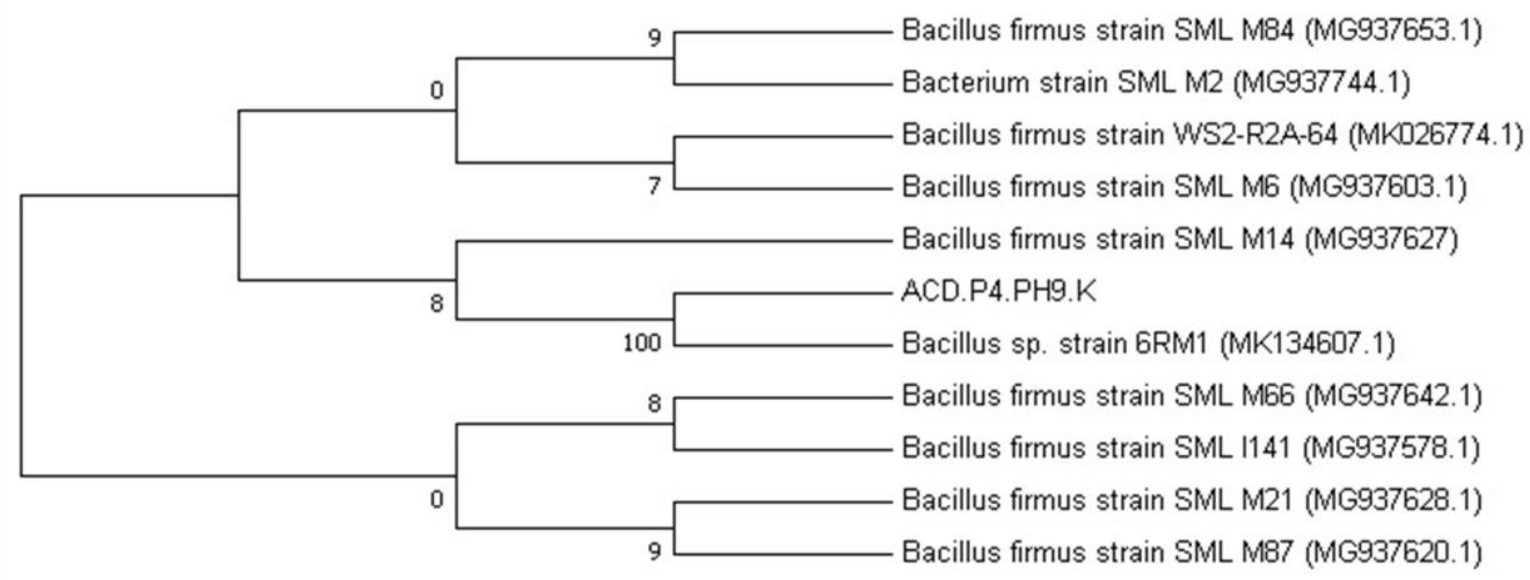

Figure 5. Phylogenic Tree of ACD.P4.PH9.K Bacteria Isolate Based on 16S rRNA Sequence Neighbor - Joining Method, Bootstrap 1000x

an identity value of $98.50 \%$. This means that from the phylogeny trees' reconstruction of a thousand times, the sequence ACD.P4.PH9.P has a $55 \%$ relationship with Bacillus sp. c234 (Acc. No. FJ950647.1). On the other hand, the ACD.P4.PH9.K sequence is closely related to the species Bacillus sp. of strain 6RM1 (Acc. No. MK134607.1, Figure 5) The obtained bootstrap value is $100 \%$ with an identity value of $94.78 \%$. This means that from the phylogeny trees' reconstruction of a thousand times, the sequence ACD.P4.PH9.K has a $100 \%$ relationship with Bacillus sp. of strain 6RM1 (Acc. No. MK134607.1).

Between the picture (Figure 4 and Figure 5), both have the same kinship, i.e. with the species Bacillus sp. which belongs to the Bacillus genus. Bacillus is a rod-shaped bacteria that is often found in land or water, including the sea. These bacteria are classified into aerobic gram-positive bacteria or facultative aerobic with several types of Bacillus producing extracellular enzymes that can hydrolyze complex proteins and polysaccharides (Hatmanti, 2000).

In addition there are several strains. A strain is a collection of several types of cells. Strains are considered as small differences found in the same bacterial species. Strain differences in bacterial species can be caused by environmental factors and evolutionary processes.

\section{Conclusions}

Based on the present study, from the isolation processes of the Acropora digitifera symbiotic bacteria, 6 isolates of pure bacteria were obtained, where 3 of them were sequenced. It was discovered that the bacteria from the isolate ACD.P4.PH7.P has a close 
relationship with Bacillus flexus of strain $\mathrm{BF}$ and zb (Acc. No. MH56956060 .1) with $85.44 \%$ similarity.

Isolate ACD.P4.PH9.P has a close relationship with Bacillus sp. c234 (Acc. No. FJ950647.1) with a similarity of $98.50 \%$. Isolate ACD.P4.PH9.K has a close relationship with the species Bacillus sp. of strain 6RM1 (Acc. No. MK134607.1) with a 94.78\% similarity. Further research should be done concerning the bacterial association with the sea water and the sediments around these coral reefs.

\section{Acknowledgements}

The author would like to thank to the Directorate of Research and Community Service Universitas Padjadjaran (Unpad) for the financial support through the scheme of Fundamental Research Unpad (RFU) granted to MUKA. The authors also thank to the students of Faculty of Fisheries and Marine Sciences for their assistance during the sampling campaign.

\section{References}

Cappuccino, James G. and Welsh, C. 2018. Microbiology a Laboratory Manual. Eleventh Edition. England: Pearson.

Claverie, J. \& Notredame, C. 2003 Bioinformatics for Dummies. Wiley Publishing, Indianapolis, USA.

Drancourt, M, Bollet, C., Carlioz, A., Martelin, R., Gayral, J., and Raoult, D. 2000. 16S Ribosomal Sequence Analysis of A Large Collection of Environmental and Clinical Unidentifiable Bacterial Isolates. Journal of Clinical Microbiology 38(10): 36233630.

Hatmanti. 2000. Pengenalan Bacillus sp. Oseana 27(1): 31-41.

Iqbal, M., Buwono, I. D., Kurniawati, N. 2016. Analisis Perbandingan Metode Isolasi DNA Untuk Deteksi White Spot Syndrome Virus (WSSV) Pada Udang Vaname (Litopenaeus vannamei). Jurnal Perikanan Kelautan 7(1): 54-65.

Lane, D. J. 1991. 16S/23S rRNA Sequencing. In: Stackebrandt, E.,Goodfellow, M., editors. Nucleic Acid Techniques in Bacterial Systematics. New York: Wiley \&
Sons; p. 115-76.

Lauro, F. M., McDougald, D., Thomas, T., Williams, T. J., Egan, S., Rice, S., Demaere, M. Z., Ting, L., Ertan, H., Johnson, J., Ferriera, S., Lapidus, A., Anderson, I., Kyrpides, N., Munk, A. C., Detter, C., Han, C. S., Brown, M. V., Robb, F. T., Kjelleberg, S., Cavicchioli, R. 2009. The genomic basis of trophic strategy in marine bacteria. PNAS 106(37): 15527-15533.

Miller, G., Beckwith, R., Fellbaum, C., Gross, D., Miller, K. 1990. Wordnet: An On line Lexical Database. International Journal of Lexicography.

Mulyani, Y., Purwanto, A., Nurruhwati, I. 2011. Perbandingan Beberapa Metode Isolasi DNA untuk Deteksi Dini Koi Herpes Virus (KHV) Pada Ikan Mas (Cyprinus carpio L.). Jurnal Akuatika 8(11): 1-16.

Napitupulu, Hatopan, G. 2019. Bacillus sp. Sebagai Agensia Pengurai Dalam Pemeliharaan Brachionus rotundiformis yang Menggunakan Ikan Mentah Sebagai Sumber Nutrisi.Jurnal IImiah Platax 7(1): 158-169.

Pangastuti, A. 2006. Definisi Spesies Prokaryota Berdasarkan Urutan Basa Gen Penyandi 16S rRNA dan Penyandi Protein. Biodiversitas 7(3): $292-296$.

Rinanda, T. 2011. Analisis Sekuensing 16S rRNA di Bidang Mikrobiologi. Jurnal Kedokteran Syiah Kuala.11(3): 172-177.

Ritchie, K. B. and Smith, G. K. 1997. Physiological Comparisons of Bacteria From Various Species of Scleractinia Corals. Dalam: Proceedings of The 8th International Symposium for Reef Studies: 521-526.

Utama, R. S., Budiyanto, A. 2017. Kondisi dan Keanekaragaman Karang Batu di Perairan Sabang. Jurnal Oseanologi dan Limnologi di Indonesia 2(1) : 69-82.

Zhang, Y. Y., Ling, L., Yang, Q., Wang, Y., Sun, C., Sun, H., Feng, J. 2015. The diversityof coral associated bacteria and the environmental factors affect their community variation. Ecotoxicology 24(7): 1467-1477 